University of South Florida

DIGITAL COMMONS

Digital Commons @ University of

@ UNIVERSITY OF SOUTH FLORIDA

South Florida

Internal Medicine Faculty Publications

Internal Medicine

$5-1-2011$

\title{
Fish Oil Concentrate Delays Sensitivity to Thermal Nociception in
}

Mice

Jyothi M. Veigas

University of Texas Health Science Center at San Antonio

Paul J. Williams

University of Texas Health Science Center at San Antonio

Ganesh Halade

University of Texas Health Science Center at San Antonio, ghalade@usf.edu

Mizanur M. Rahman

University of Texas Health Science Center at San Antonio

Toshiyuki Yoneda

University of Texas Health Science Center at San Antonio

See next page for additional authors

Follow this and additional works at: https://digitalcommons.usf.edu/intmed_facpub

\section{Scholar Commons Citation}

Veigas, Jyothi M.; Williams, Paul J.; Halade, Ganesh; Rahman, Mizanur M.; Yoneda, Toshiyuki; and Fernandes, Gabriel, "Fish Oil Concentrate Delays Sensitivity to Thermal Nociception in Mice" (2011). Internal Medicine Faculty Publications. 70.

https://digitalcommons.usf.edu/intmed_facpub/70

This Article is brought to you for free and open access by the Internal Medicine at Digital Commons @ University of South Florida. It has been accepted for inclusion in Internal Medicine Faculty Publications by an authorized administrator of Digital Commons @ University of South Florida. For more information, please contact digitalcommons@usf.edu. 


\section{Authors}

Jyothi M. Veigas, Paul J. Williams, Ganesh Halade, Mizanur M. Rahman, Toshiyuki Yoneda, and Gabriel Fernandes 


\title{
Fish oil concentrate delays sensitivity to thermal nociception in mice
}

\author{
Jyothi M. Veigas ${ }^{\mathrm{a}}$, Paul J. Williams ${ }^{\mathrm{a}}$, Ganesh Halade ${ }^{\mathrm{a}}$, Mizanur M. Rahmana ${ }^{\mathrm{a}}$, Toshiyuki \\ Yoneda $^{\mathrm{a}, \mathrm{b}}$, and Gabriel Fernandes ${ }^{\mathrm{a},{ }^{,}}$ \\ aDepartment of Medicine, Division of Clinical Immunology and Rheumatology, UTHSCSA, San \\ Antonio, Texas \\ bDepartment of Molecular and Cellular Biochemistry, Osaka University Graduate School of \\ Dentistry, Suita, Osaka
}

\begin{abstract}
Fish oil has been used to alleviate pain associated with inflammatory conditions such as rheumatoid arthritis. The anti-inflammatory property of fish oil is attributed to the n-3 fatty acids docosahexaenoic acid and eicosapentaenoic acid. Contrarily, vegetable oils such as safflower oil are rich in $n-6$ fatty acids which are considered to be mediators of inflammation. This study investigates the effect of n-3 and n-6 fatty acids rich oils as dietary supplements on the thermally induced pain sensitivity in healthy mice. $\mathrm{C} 57 \mathrm{Bl} / 6 \mathrm{~J}$ mice were fed diet containing regular fish oil, concentrated fish oil formulation (CFO) and safflower oil (SO) for 6 months. Pain sensitivity was measured by plantar test and was correlated to the expression of acid sensing ion channels (ASICs), transient receptor potential vanilloid 1 (TRPV1) and c-fos in dorsal root ganglion cells. Significant delay in sensitivity to thermal nociception was observed in mice fed CFO compared to mice fed $\mathrm{SO}(\mathrm{p}<0.05)$. A significant diminution in expression of ion channels such as ASIC1a (64\%), ASIC13 (37\%) and TRPV1 (56\%) coupled with reduced expression of c-fos, a marker of neuronal activation, was observed in the dorsal root ganglion cells of mice fed CFO compared to that fed SO. In conclusion, we describe here the potential of fish oil supplement in reducing sensitivity to thermal nociception in normal mice.
\end{abstract}

\section{Keywords}

n-3 fatty acids; pain; fish oil; ASIC; TRPV1; c-fos

\section{Introduction}

Pain is an important debilitating factor, especially during aging and under conditions of existing pathologies. While aging does not automatically induce pain, it may alter a person's ability to respond to pain effectively. Chronic pain negatively affects the quality of life and

\footnotetext{
(C) 2011 Elsevier Ltd. All rights reserved.

*Address for correspondence: Gabriel Fernandes, Ph.D, Professor of Medicine, Physiology and Microbiology and Immunology, Department of Medicine, Division of Clinical Immunology and Rheumatology, University of Texas Health Science Center at San Antonio, 7703 Floyd Curl Drive, San Antonio, Texas, USA 78229, fernandes@uthscsa.edu, Phone: 1-210-567-4679, Fax: 1-210-567-4592.

Publisher's Disclaimer: This is a PDF file of an unedited manuscript that has been accepted for publication. As a service to our customers we are providing this early version of the manuscript. The manuscript will undergo copyediting, typesetting, and review of the resulting proof before it is published in its final citable form. Please note that during the production process errors may be discovered which could affect the content, and all legal disclaimers that apply to the journal pertain.
} 
is one of the leading causes of depression. However, it is possible to manage pain, physiological as well as pathological, by adopting a suitable nutritional strategy and/or by using dietary supplements [1]. This approach is now being advocated as an alternative to pain killer drugs. Nevertheless, with the existence of an ever expanding multi-billion dollar market for anti-inflammatory pharmaceutical drugs, the benefits of dietary supplements largely remain repressed.

Dietary fatty acids play an important role in determining the body's inflammation status. While $n-6$ fatty acids are known to be precursors of inflammatory mediators, $n-3$ fatty acids are known to possess anti-inflammatory properties. We have earlier reported the beneficial effects of n-3 fatty acids on inhibition of autoimmunity and osteoporosis in mice [2-4]. Apparently, it is the ratio of n-6 to $n-3$ fatty acids rather than the absolute quantity of fatty acids that is critical to their health benefits [5]. A higher ratio of n-6/n-3 fatty acids mostly favors inflammation. While the optimum ratio is thought to be $4: 1$, the current Western diet is largely deficient in n-3 fatty acids with this ratio ranging from 10:1 to 20-25:1 [6,7]. Further, high level of arachidonic acid (AA), a precursor of 4-series leukotrienes (LT) and the chief inflammatory metabolite of linoleic acid (n-6 fatty acid), is responsible for a cascade of events leading to inflammation, pain and manifestation of several disorders [810]. Arachidonic acid is also a precursor of inflammatory prostaglandins (PG) which sensitize pain receptors on nerve endings through their action on ion channels [10,11]. Nutritional intervention may largely influence the modulation inflammation [12]. For example, a diet low in arachidonic acid (n-6 fatty acid) has shown to reduce the clinical signs of inflammation in rheumatoid arthritis patients and also to augment the benefits of fish oil supplementation with an accompanying increase in eicosapentaenoic acid (EPA, 20:5 n-3) in erythrocyte lipids and consequent reduction in inflammatory eicosanoids [13]. Therefore a diet low in $\mathrm{n}-6$ fatty acids and high in $\mathrm{n}-3$ fatty acids is desirable for a healthy living.

Omega-3 fatty acids (n-3 fatty acids) possess strong anti-inflammatory and analgesic properties. DHA and EPA are precursors of potent anti-inflammatory lipid mediators such as resolvins and protectins [14]. Fish oil, a rich source of n-3 fatty acids such as EPA and docosahexaenoic acid (DHA, 22:6 n-3), is often used as dietary supplement by rheumatoid arthritis patients to alleviate joint pain [15]. Several studies have also shown that an increased intake of $n-3$ polyunsaturated fatty acids (PUFA) is associated with reduced pain in rheumatoid arthritis [15], inflammatory bowel disease [16] and dysmenorrhea [17]. Rats treated with n-3 fatty acids have shown to markedly increase threshold for thermal pain [5]. Recently, Shapiro [18] suggested that n-3 PUFA might relieve pain by their direct action on neurones. High dose of fish oil has also shown to significantly reduce circulating proinflammatory cytokines, physician's evaluation of pain and other clinical parameters in rheumatoid arthritis patients, post discontinuation of non-steroidal anti-inflammatory drugs (NSAIDs) [19]. A recent study has suggested clinically significant reduction of neuropathic pain in human subjects [20]. While most studies reporting the effect of $n-3$ fatty acids on pain mainly refer to injury-induced neuropathic pain $[21,22]$ or pathological pain $[15,23]$, very few studies are available on their effect on sensitivity to nociception in normal subjects [5,24]. A most recent study demonstrated the effect of DHA against thermal and chemical nociception in a mouse model, where the mice were administered different doses of DHA 30 minutes before the test measurements [25]. However, despite many reports on the analgesic effects of n-3 fatty acids, the mechanisms through which they delay pain sensitivity are not fully understood. One study demonstrated inhibition of transient receptor potential vanilloid subfamily 1 (TRPV1) currents by EPA in vitro in Xenopus oocyte model and also a reduction of capsaicin-induced pain behavior in mice [26]. Interestingly, the authors also demonstrated the TRPV1 agonistic activity of DHA through direct activation of the ion 
channel. However, the antagonistic activity of EPA was not accompanied by data on expression of TRPV1 in vivo [26].

Therefore, the present study was aimed at testing the differential effects of long term consumption of concentrated n-3 fatty acids-rich fish oil (CFO), regular fish oil (FO) and $\mathrm{n}-6$ fatty acids-rich safflower oil (SO) on thermally induced pain sensitivity in healthy aging mice and elucidating the mechanisms therein. Concentrated FO used in the study is a FDA approved prescription drug and contains high concentrations of EPA (46.5\%) and DHA (37.5\%) [27]. Regular FO contains 18\% EPA and 12\% DHA. We selected SO as a source of $\mathrm{n}-6$ fatty acids to emphasize the mechanism for increased nociception and compare against the benefits of fish oil.

\section{Materials and Methods}

\subsection{Oils}

Concentrated fish oil was obtained from Glaxo SmithKline, (Waltham, MA) and safflower oil was obtained from MP Biomedicals (Solon, Ohio).

\subsection{Animals and diet}

Eleven month-old female C57Bl/6J mice, weighing 24-25g, were purchased from Jackson Laboratories (Bar Harbor, Maine 04609 USA) and provided water and standard chow AIN93G (diet recommended by AIN for growth) ad libitum for one month. At twelve months, weight matched animals were divided into three groups, each containing 20 mice. Subsequently, the animals were housed in a standard controlled animal care facility in cages ( 5 mice/cage) and group I was fed a diet containing $4 \%$ regular FO, group II was fed diet containing 4\% CFO and group III was fed diet containing 5\% SO diet ad libitum for 6 months. The oil concentration in the fish oil diet was made up to $5 \%$ with SO. The animals were maintained in a temperature controlled room $\left(22-25^{\circ} \mathrm{C}, 45 \%\right.$ humidity) on a $12: 12-\mathrm{h}$ dark-light cycle. National Institutes of Health guidelines were strictly followed, and all the studies were approved by the Institutional Laboratory Animal Care and Use Committee of the University of Texas Health Science Center at San Antonio (San Antonio, TX). Body weight was measured weekly. The diets were prepared using AIN-93G semi-purified powdered ingredients (Table 1).

\subsection{Paw withdrawal latency (Plantar test)}

Paw withdrawal response to thermal stimuli of radiant heat was measured using a device (Plantar test, 7370; Ugo Basile, Comerio, Italy) as described previously [28,29]. Briefly, mice were acclimatized to an $8 " \times 8 "$ clear plexiglass box on a plexiglass floor for one hour before testing. The plantar surface of the hind paw was exposed to an infrared radiant heat source positioned under the plexiglass floor. The paw withdrawal latencies were measured electronically three times per session, separated by a minimum interval of $5 \mathrm{~min}$. Paw withdrawals due to locomotion or weight shifting were not counted, and the trials were repeated. Data are expressed as paw withdrawal latency in seconds.

\subsection{Isolation of mouse L3-L5 DRG's}

After 6 months on the experimental diet, the mice were killed under anesthesia. Fresh mouse L3-L5 dorsal root ganglions (DRGs) were isolated as described elsewhere [30]. In brief, mice were laid in the prone position and the spinal cord and the segmental distribution of the DRG was exposed by making an incision across the spine. Parallel cuts were then made through the vertebrae adjacent to the spinal cord, and the overlying muscle and bone were removed. The last thoracic ganglion (T13) and the ganglion with the greatest contribution to the sciatic nerve (L4) were identified for orientation with respect to the whole mouse. The 
dorsal roots are very short at the cervical and upper thoracic levels, and the ganglia lie closely apposed to the spinal cord. L3-L5 DRG's were removed, and placed in cold saline solution. DRG's were then processed either for RT-PCR, hematoxylin/eosin or c-fos immuno-staining.

\subsection{Hematoxylin \& Eosin staining of DRGs}

DRGs at lumbar level L3-L5 were removed, fixed in 10\% formalin for $24 \mathrm{~h}$ and processed and embedded in paraffin. Serial sections ( $5 \mu \mathrm{m}$ thick) were made using a sliding microtome and standard hematoxylin and eosin (H\&E) staining was performed for structural verification of the sections.

\subsection{Immuno-histochemistry of c-fos in mouse DRGs}

Sections of DRGs were processed for c-fos immunohistochemistry according to Iwata et al [31]. After removal, the DRGs were immersed in formalin fixative for $72 \mathrm{~h}$. Tissues were processed in the standard manner, embedded in paraffin and $5 \mu \mathrm{m}$ sections were cut with a microtome. Sections were incubated in $1.5 \%$ normal goat serum (NGS) and $0.1 \%$ bovine serum albumin (BSA, Sigma, St. Louis, MO, USA) for $24 \mathrm{~h}$ at $4^{\circ} \mathrm{C}$. Next, the sections were incubated for $72 \mathrm{~h}$ in rabbit anti-c-fos (1:2000; Oncogene Science, Cambridge, MA, USA) at $4^{\circ} \mathrm{C}$. Subsequently, the sections were incubated in biotinylated goat anti-rabbit (1:200; Vector Labs, Burlingame, CA, USA) for $1 \mathrm{~h}$ at $37^{\circ} \mathrm{C}$ and peroxidase-conjugated avidinbiotin complex (1:100; $\mathrm{ABC}$, Vector Labs) for $4 \mathrm{~h}$ at $25^{\circ} \mathrm{C}$. To develop the $\mathrm{ABC}$ reaction product, the sections were incubated in $0.035 \%$ 3,3'-diaminobenzidine-tetra $\mathrm{HCl}$ (DAB; Sigma) and $0.05 \%$ peroxide in $0.05 \mathrm{M}$ Tris-buffer (TB, $\mathrm{pH} 7.4$ ), resulting in a distinctive deposit of brown granules on the nuclei of cells. Between each incubation, sections were rinsed three times by $0.01 \mathrm{M}$ PBS for $15 \mathrm{~min}$. Every other section was counterstained with hematoxylin.

\subsection{Reverse transcriptase-polymerase chain reaction (RT-PCR)}

Fresh mouse dorsal root ganglions (DRGs) (L3-L5) were dissected following the protocol as described earlier. Total RNA was isolated using RNAeasy Mini-kit (Qiagen, Valencia, CA). Single-strand cDNA was synthesized from $0.4 \mu \mathrm{g}$ RNA using Superscript III firststrand kit (Invitrogen, Carlsbad, CA). The expression levels of ASIC1a, ASCI3 and TRPV1 were assessed with 10ng total RNA using Taqman Gene Expression Assays (Applied Biosystems) in an Applied Biosystems 7900HT Sequence Detection System according to manufacturer's instructions. Appropriate negative controls (no-template control) were also run in each reaction. Relative quantification was obtained using $2^{-\Delta \Delta \mathrm{Ct}}$ after normalization of the $\mathrm{C}_{\mathrm{t}}$ data to that of the housekeeping gene, GAPDH, where $\mathrm{C}_{\mathrm{t}}$ is the threshold cycle of fluorescence detection.

\section{Statistical analysis}

Data are presented as mean values \pm SEM. Students' $t$-test was used to evaluate differences between samples of fish oil diet group with the corresponding SO diet group as the control samples. $p \leq 0.05$ was considered statistically significant. The analyses were performed using GraphPad prism for Windows (La Jolla, CA, USA).

\section{Results}

\subsection{Effect of FO and SO on response time to thermal nociception}

Response to thermal hyperalgesia was measured by exposing the plantar region of paw of mice $(n=6)$ to a source of radiant heat. An increase in withdrawal response time was observed in C57B1/6J mice fed CFO $(13.52 \pm 1.3 \mathrm{sec})$ and FO $(11.04 \pm 0.61 \mathrm{sec})$ enriched diet 
compared to that in mice fed SO rich diet, which showed paw withdrawal response at $9.28 \pm 0.62 \mathrm{sec}$. Resistance to thermal nociception was significantly higher in CFO fed mice $(\mathrm{p}<0.05)$ compared to SO fed mice while it was not statistically significant in regular FO fed mice suggesting a significant reduction in sensitivity to heat induced pain in mice supplemented with CFO (Fig. 1A). The test was also carried out on BW mice fed experimental diets for six months and the results showed significantly reduced sensitivity in CFO fed mice (Fig. 1B).

Since mice fed regular FO did not show significant increase in resistance to thermally induced nociception compared to SO fed mice, this group was excluded from further analysis.

\subsection{Effect on c-fos protein immunoreactivity in DRG}

Immunohistochemical staining of DRGs, isolated from mice fed CFO and SO diets, using cfos antibody revealed dark brown granular structures representing c-fos protein (Fig. 2B). The relative area of immunoreactivity was significantly lower in DRGs isolated from CFO fed mice $\left(5.12 \pm 0.31 \mu \mathrm{m}^{2}\right)$ as compared to that from SO fed mice $\left(7.23 \pm 0.63 \mu \mathrm{m}^{2}\right)$ at $\mathrm{p}<0.05$ (Fig. 2C).Effect on pain sensing genes in DRG: To evaluate the molecular changes involved in thermal nociception, we determined the mRNA expression of acid sensing ion channels, ASIC1a, and ASIC3 as well as the cation channel, TRPV1 in DRGs of mice fed CFO and SO enriched diets. The DRGs from L3-L5 were used for mRNA isolation since the sensory $n \mathrm{e}^{\mathrm{r}} \mathrm{ves}$ originating from this region innervate the limbs. Expression of pain genes was normalized to the housekeeping gene, GAPDH. Reduction in the relative expression level of mRNAs of ASIC1a, ASIC13 $(\mathrm{p}<0.05)$ and TRPV1 $(\mathrm{p}<0.001)$ was significant and was recorded to be $64 \%, 37 \%$ and $56 \%$ respectively in DRGs of CFO fed mice compared to that of SO fed mice.

\section{Discussion}

Pain is a consequence of an inflammatory status of the body. One of the factors that govern inflammation is the balance between dietary $n-6$ and $n-3$ fatty acids which act as precursors of inflammatory and anti-inflammatory lipid mediators respectively, through the action of the enzymes cycloxygenase (COX) and lipoxygenase (LOX). It is believed that a high concentration of $n-6$ fatty acids in the diet promotes inflammation due to increased arachidonic acid (AA) level which is the chief precursor of inflammatory mediators such as 2 series prostaglandins (PGs) and 4 series leukotrienes (LTs). PGs and LTs increase vascular permeability and sensitize pain receptors $[32,33]$ leading to increased sensitivity to pain. However, when a diet predominantly contains n- 3 fatty acids such as EPA and DHA, these fatty acids compete with AA as substrates for COX and LOX to form anti-inflammatory, PGE3 and LT5 [34,35]. We have shown, in the present study, that mice fed a CFO supplemented diet exhibited a modest but statistically significant reduction in sensitivity to thermal nociception as compared to mice on SO supplemented diet. It appears that the high concentration of n-3 fatty acids, EPA and DHA in CFO is largely responsible for reduced pain sensitivity since no significant effect was observed in mice fed regular FO.

To understand the mechanisms involved, we studied the changes in the expression of c-fos protein and pain sensing genes. C-fos, an immediate early gene, is a powerful marker of neuronal activation and though not specific, is considered a neural marker of pain [36]. Immunoreactivity of c-fos was significantly higher in DRG of SO supplemented mice compared to CFO fed mice. Apparently, AA and its metabolites (PGs) stimulate the mRNA expression of $\mathrm{c}$-fos and blocking the $\mathrm{PG}$ production through COX inhibition abolishes the expression of AA induced mRNA [37] as well as protein expression of c-fos [38].

Stimulatory effect of AA is believed to be mediated via synthesis of PGE2 and subsequent 
activation of protein kinase C possibly through PGE2 receptor coupled to phospholipase C. However, this stimulatory effect was not reproduced with structurally similar compounds [37] suggesting the specificity of AA as a stimulus for c-fos induction. Additionally, the elevated levels of pro-inflammatory cytokines like IL-6 may also have a stimulatory effect on c-fos activation [39]. We have earlier shown that high levels of endogenous n-3 fatty acids reduce circulating inflammatory cytokines such as TNF $\alpha$ and IL-6 in Fat-1 mice [40]. Yoneda et al [29] have earlier reported that hyperalgesia is associated with an increase in cfos immunoreactivity accompanied by activation of ASICs. Therefore, the increased c-fos expression in SO fed mice may be indicative of amplified neuronal activation and consequent increased sensitivity to thermal nociception.

Furthermore, acid-sensing ion channels, such as ASIC1a, ASIC1b and ASIC3 and transient receptor potential vanilloid 1 (TRPV1), are implicated in pain perception [41]. Activation of these ion channels is a complex mechanism and involves one or more factors such as proton sensitive ion channels, the ASICs and transient receptor potential cation channels being the most important ones involved in pain perception [41]. Acid sensing ion channels which are present on the nociceptive sensory neurones are activated by proton-gated depolarizing currents [42]. Arachidonic acid is known to produce high proton concentrations (acidosis) under physiological as well as pathological conditions $[43,44]$ and tissue acidosis is believed to be yet another cause of inflammation and pain [45]. ASIC3 is most sensitive to changes in tissue acidity [46]. In the present study expression of both ASIC1a and ASIC3 were significantly reduced by fish oil diet compared with SO fed mice. TRPV1 was also significantly affected by the diets and it is believed to play a central role in proton detection [47] and hence pain perception. It is also suggested that inflammatory acidic environments activate TRPV1 leading to series of events involved in inflammatory pain [48]. Given the overall increase in inflammatory markers in SO fed mice, we presume that there may be an increased intracellular or extracellular protons concentration which may result in activation of a variety of ion channels involved in pain perception [49]. However, in the absence of concrete data on the tissue $\mathrm{pH}$, these claims are only presumptive and warrant further studies to correlate pain with tissue $\mathrm{pH}$, ion channel activation and cytokine production.

Further, oxidized linoleic acid metabolites such as 9- and 13-hydroxyoctadecadienoic acid (9-HODE/13-HODE) are found to activate TRPV1 in the spinal cord contributing to hyperalgesia [50]. TRPV1 is shown to selectively mediate thermal nociception [51]. We observed, for the very first time, that mRNA expression of ASIC1a, ASIC3 and TRPV1 was significantly lower in $\mathrm{CFO}$ fed mice, when compared to $\mathrm{SO}$ fed mice, suggesting a reduced inflammatory status which may be the reason for increased pain threshold in the former group. It is known that fish oil, which contains n-3 fatty acids, possesses analgesic property and is used in various inflammatory disorders to alleviate pain [17,19,23,52]. Further, since SO is chiefly composed of linoleic acid, it may be possible that it is metabolized to 9- and 13-hydroxy-octadecadienoic acids (HODEs) [53,54] apart from AA and reduce the pain threshold in mice fed SO supplemented diet. Since formation of HODEs is inhibited by COX and LOX inhibitors [53,55], supplementing n-3 fatty acids may preferentially utilize these enzymes for the production of less potent PGE3 and LTB5. The analgesic property of n-3 fatty acids is also attributed to their ability to generate resolvins and protectins in vivo. For example, DHA and EPA, act as precursors of D series (RvD1, RvD2) and E-series (RvE1, RvE2) of resolvins respectively, which exhibit potent anti-inflammatory properties [56]. A recent study has shown resolvins to normalize synaptic plasticity in spinal cord dorsal horn neurons thus reducing hypersensitivity to inflammatory pain [57].

The use of fish oil has been suggested to be useful in reducing the dose of NSAIDs for chronic inflammatory disorders [58,59] and as safer alternatives to NSAIDs [52]. NSAIDs mainly act through inhibition of COX. Since fish oil fatty acids require COX to form the 
anti-inflammatory PGs and LTs, theoretically, analgesic effects resulting from its coadministration with NSAID should be attributed to the latter alone. From this it appears that fish oil fatty acids may not be solely dependent on eicosanoid production for its analgesic effect but may act independently through mechanisms involving cytokines, pain sensing ion channels and other transcriptional factors.

\section{Conclusion}

This work contributes to the mechanistic overview for justifying the already existing data on anti-inflammatory and antihyperalgesic effects of n-3 fatty acids. Furthermore, the new information that it does so by partly acting through acid sensing ion channels and neuronal activators, adds to better understanding of its mechanisms. Further studies on the effect of fish oil on other nociceptive modalities like chemical and mechanical nociception are warranted to confirm this data on thermal nociception.

\section{Acknowledgments}

This pilot study was presented at the $21^{\text {st }}$ Annual Clinical Meeting of American Association of Pain Management. We thank GlaxoSmithKline for free supply of concentrated fish oil (Lovaza) for the study. The study was supported by grant AT 004259-02 from the National Institutes of Health and BC096459 from Department of Defense.

\section{References}

1. Sulindro-Ma, MIC.; Isenhart, AC. Nutrition and supplements for pain management. In: Audette, JABA., editor. Integrative pain medicine. USA: Humana Press; 2008. p. 417-445.

2. Bhattacharya A, Rahman M, Banu J, Lawrence RA, McGuff HS, Garrett IR, Fischbach M, Fernandes G. Inhibition of osteoporosis in autoimmune disease prone $\mathrm{mrl} / \mathrm{mpj}$-fas(lpr) mice by $\mathrm{n}-3$ fatty acids. Journal of the American College of Nutrition. 2005; 24:200-209. [PubMed: 15930486]

3. Chandrasekar B, Troyer DA, Venkatraman JT, Fernandes G. Dietary omega-3 lipids delay the onset and progression of autoimmune lupus nephritis by inhibiting transforming growth-factor-beta messenger-rna and protein expression. Journal of Autoimmunity. 1995; 8:381-393. [PubMed: 7575999]

4. Halade GV, Rahman MM, Bhattacharya A, Barnes JL, Chandrasekar B, Fernandes G. Docosahexaenoic acid-enriched fish oil attenuates kidney disease and prolongs median and maximal life span of autoimmune lupus-prone mice. Journal of Immunology. 2010; 184:5280-5286.

5. Yehuda S, Carasso RL. Modulation of learning, pain thresholds, and thermoregulation in the rat by preparations of free purified alpha-linolenic and linoleic acids: Determination of the optimal omega 3-to-omega 6 ratio. Proc Natl Acad Sci U S A. 1993; 90:10345-10349. [PubMed: 7901853]

6. Simopoulos AP. Omega-3 fatty acids in health and disease. Prog Clin Biol Res. 1990; 326:129-156. [PubMed: 2405415]

7. Simopoulos AP. The importance of the ratio of omega-6/omega-3 essential fatty acids. Biomed Pharmacother. 2002; 56:365-379. [PubMed: 12442909]

8. Funk CD. Prostaglandins and leukotrienes: Advances in eicosanoid biology. Science. 2001; 294:1871-1875. [PubMed: 11729303]

9. Khanapure SP, Garvey DS, Janero DR, Letts LG. Eicosanoids in inflammation: Biosynthesis, pharmacology, and therapeutic frontiers. Curr Top Med Chem. 2007; 7:311-340. [PubMed: 17305573]

10. Davies P, Bailey PJ, Goldenberg MM, Ford-Hutchinson AW. The role of arachidonic acid oxygenation products in pain and inflammation. Annu Rev Immunol. 1984; 2:335-357. [PubMed: 6100476]

11. Meves H. The action of prostaglandins on ion channels. Curr Neuropharmacol. 2006; 4:41-57. [PubMed: 18615137]

12. Visioli F, Poli A, Richard D, Paoletti R. Modulation of inflammation by nutritional interventions. Curr Atheroscler Rep. 2008; 10:451-453. [PubMed: 18937889] 
13. Adam O, Beringer C, Kless T, Lemmen C, Adam A, Wiseman M, Adam P, Klimmek R, Forth W. Anti-inflammatory effects of a low arachidonic acid diet and fish oil in patients with rheumatoid arthritis. Rheumatol Int. 2003; 23:27-36. [PubMed: 12548439]

14. Serhan CN, Gotlinger K, Hong S, Arita M. Resolvins, docosatrienes, and neuroprotectins, novel omega-3-derived mediators, and their aspirin-triggered endogenous epimers: An overview of their protective roles in catabasis. Prostaglandins Other Lipid Mediat. 2004; 73:155-172. [PubMed: 15290791]

15. Ruggiero C, Lattanzio F, Lauretani F, Gasperini B, Andres-Lacueva C, Cherubini A. Omega-3 polyunsaturated fatty acids and immune-mediated diseases: Inflammatory bowel disease and rheumatoid arthritis. Curr Pharm Des. 2009; 15:4135-4148. [PubMed: 20041815]

16. Belluzzi A, Boschi S, Brignola C, Munarini A, Cariani G, Miglio F. Polyunsaturated fatty acids and inflammatory bowel disease. Am J Clin Nutr. 2000; 71:339S-342S. [PubMed: 10617993]

17. Harel Z, Biro FM, Kottenhahn RK, Rosenthal SL. Supplementation with omega-3 polyunsaturated fatty acids in the management of dysmenorrhea in adolescents. Am J Obstet Gynecol. 1996; 174:1335-1338. [PubMed: 8623866]

18. Shapiro H. Could n-3 polyunsaturated fatty acids reduce pathological pain by direct actions on the nervous system? Prostaglandins Leukot Essent Fatty Acids. 2003; 68:219-224. [PubMed: 12591006]

19. Kremer JM, Lawrence DA, Petrillo GF, Litts LL, Mullaly PM, Rynes RI, Stocker RP, Parhami N, Greenstein NS, Fuchs BR, et al. Effects of high-dose fish oil on rheumatoid arthritis after stopping nonsteroidal antiinflammatory drugs. Clinical and immune correlates. Arthritis Rheum. 1995; 38:1107-1114. [PubMed: 7639807]

20. Ko GD, Nowacki NB, Arseneau L, Eitel M, Hum A. Omega-3 fatty acids for neuropathic pain: Case series. Clin J Pain. 26:168-172. [PubMed: 20090445]

21. Perez J, Ware MA, Chevalier S, Gougeon R, Shir Y. Dietary omega-3 fatty acids may be associated with increased neuropathic pain in nerve-injured rats. Anesth Analg. 2005; 101:444448. table of contents. [PubMed: 16037160]

22. Martin YB, Avendano C. Effects of removal of dietary polyunsaturated fatty acids on plasma extravasation and mechanical allodynia in a trigeminal neuropathic pain model. Mol Pain. 2009; 5:8. [PubMed: 19243598]

23. Kremer JM. N-3 fatty acid supplements in rheumatoid arthritis. Am J Clin Nutr. 2000; 71:349S351S. [PubMed: 10617995]

24. Yehuda S, Leprohon-Greenwood CE, Dixon LM, Coscina DV. Effects of dietary fat on pain threshold, thermoregulation and motor activity in rats. Pharmacol Biochem Behav. 1986; 24:17751777. [PubMed: 3737642]

25. Nakamoto K, Nishinaka T, Mankura M, Fujita-Hamabe W, Tokuyama S. Antinociceptive effects of docosahexaenoic acid against various pain stimuli in mice. Biol Pharm Bull. 33:1070-1072. [PubMed: 20522981]

26. Matta JA, Miyares RL, Ahern GP. Trpv1 is a novel target for omega-3 polyunsaturated fatty acids. J Physiol. 2007; 578:397-411. [PubMed: 17038422]

27. Pratt CM, Reiffel JA, Ellenbogen KA, Naccarelli GV, Kowey PR. Efficacy and safety of prescription omega-3-acid ethyl esters for the prevention of recurrent symptomatic atrial fibrillation: A prospective study. Am Heart J. 2009; 158:163-169. e161-163. [PubMed: 19619690]

28. Hargreaves K, Dubner R, Brown F, Flores C, Joris J. A new and sensitive method for measuring thermal nociception in cutaneous hyperalgesia. Pain. 1988; 32:77-88. [PubMed: 3340425]

29. Nagae M, Hiraga T, Wakabayashi H, Wang L, Iwata K, Yoneda T. Osteoclasts play a part in pain due to the inflammation adjacent to bone. Bone. 2006; 39:1107-1115. [PubMed: 16769263]

30. Malin SA, Davis BM, Molliver DC. Production of dissociated sensory neuron cultures and considerations for their use in studying neuronal function and plasticity. Nat Protoc. 2007; 2:152160. [PubMed: 17401349]

31. Iwata K, Takahashi O, Tsuboi Y, Ochiai H, Hibiya J, Sakaki T, Yamaguchi Y, Sumino R. Fos protein induction in the medullary dorsal horn and first segment of the spinal cord by tooth-pulp stimulation in cats. Pain. 1998; 75:27-36. [PubMed: 9539671] 
32. Pitchford S, Levine JD. Prostaglandins sensitize nociceptors in cell culture. Neurosci Lett. 1991; 132:105-108. [PubMed: 1724065]

33. Taylor-Clark TE, Undem BJ, Macglashan DW Jr, Ghatta S, Carr MJ, McAlexander MA. Prostaglandin-induced activation of nociceptive neurons via direct interaction with transient receptor potential a1 (trpa1). Mol Pharmacol. 2008; 73:274-281. [PubMed: 18000030]

34. Calder PC. N-3 polyunsaturated fatty acids, inflammation, and inflammatory diseases. Am J Clin Nutr. 2006; 83:1505S-1519S. [PubMed: 16841861]

35. James MJ, Gibson RA, Cleland LG. Dietary polyunsaturated fatty acids and inflammatory mediator production. Am J Clin Nutr. 2000; 71:343S-348S. [PubMed: 10617994]

36. Harris JA. Using c-fos as a neural marker of pain. Brain Res Bull. 1998; 45:1-8. [PubMed: 9434195]

37. Danesch U, Weber PC, Sellmayer A. Arachidonic acid increases c-fos and egr-1 mrna in 3t3 fibroblasts by formation of prostaglandin e2 and activation of protein kinase c. J Biol Chem. 1994; 269:27258-27263. [PubMed: 7961634]

38. Mackowiak M, Czyrak A, Wedzony K. Inhibition of arachidonic acid cascade attenuates the induction of c-fos proteins by doi, 5-ht $2 \mathrm{a} / 2 \mathrm{c}$ receptor agonist, in the rat cortex. Pol J Pharmacol. 2002; 54:73-76. [PubMed: 12020047]

39. McKay S, Bromhaar MM, de Jongste JC, Hoogsteden HC, Saxena PR, Sharma HS. Proinflammatory cytokines induce c-fos expression followed by il-6 release in human airway smooth muscle cells. Mediators Inflamm. 2001; 10:135-142. [PubMed: 11545250]

40. Rahman M, Halade GV, Bhattacharya A, Fernandes G. The fat-1 transgene in mice increases antioxidant potential, reduces pro-inflammatory cytokine levels, and enhances ppar-gamma and sirt-1 expression on a calorie restricted diet. Oxid Med Cell Longev. 2009; 2:307-316. [PubMed: 20716918]

41. Julius D, Basbaum AI. Molecular mechanisms of nociception. Nature. 2001; 413:203-210. [PubMed: 11557989]

42. Voilley N. Acid-sensing ion channels (asics): New targets for the analgesic effects of non-steroid anti-inflammatory drugs (nsaids). Curr Drug Targets Inflamm Allergy. 2004; 3:71-79. [PubMed: 15032643]

43. Wu ML, Chan CC, Su MJ. Possible mechanism(s) of arachidonic acid-induced intracellular acidosis in rat cardiac myocytes. Circ Res. 2000; 86:E55-E62. [PubMed: 10679491]

44. Tzingounis AV, Lin CL, Rothstein JD, Kavanaugh MP. Arachidonic acid activates a proton current in the rat glutamate transporter eaat4. J Biol Chem. 1998; 273:17315-17317. [PubMed: 9651313]

45. Steen KH, Steen AE, Kreysel HW, Reeh PW. Inflammatory mediators potentiate pain induced by experimental tissue acidosis. Pain. 1996; 66:163-170. [PubMed: 8880837]

46. Deval E, Noel J, Lay N, Alloui A, Diochot S, Friend V, Jodar M, Lazdunski M, Lingueglia E. Asic3, a sensor of acidic and primary inflammatory pain. EMBO J. 2008; 27:3047-3055. [PubMed: 18923424]

47. Fischer MJ, Reeh PW, Sauer SK. Proton-induced calcitonin gene-related peptide release from rat sciatic nerve axons, in vitro, involving trpv1. Eur J Neurosci. 2003; 18:803-810. [PubMed: 12925006]

48. Nakanishi M, Hata K, Nagayama T, Sakurai T, Nishisho T, Wakabayashi H, Hiraga T, Ebisu S, Yoneda T. Acid activation of trpv1 leads to an up-regulation of calcitonin gene related peptide expression in dorsal root ganglion neurons via the camk-creb cascade: A potential mechanism of inflammatory pain. Mol Biol Cell.

49. Holzer P. Acid-sensitive ion channels in gastrointestinal function. Curr Opin Pharmacol. 2003; 3:618-625. [PubMed: 14644014]

50. Patwardhan AM, Scotland PE, Akopian AN, Hargreaves KM. Activation of trpv1 in the spinal cord by oxidized linoleic acid metabolites contributes to inflammatory hyperalgesia. Proc Natl Acad Sci U S A. 2009; 106:18820-18824. [PubMed: 19843694]

51. Mishra SK, Hoon MA. Ablation of trpv1 neurons reveals their selective role in thermal pain sensation. Mol Cell Neurosci. 43:157-163. [PubMed: 19853036] 
52. Maroon JC, Bost JW. Omega-3 fatty acids (fish oil) as an anti-inflammatory: An alternative to nonsteroidal anti-inflammatory drugs for discogenic pain. Surg Neurol. 2006; 65:326-331. [PubMed: 16531187]

53. Engels F, Kessels GC, Schreurs AJ, Nijkamp FP. Production of arachidonic acid and linoleic acid metabolites by human bronchoalveolar lavage cells. Prostaglandins. 1991; 42:441-450. [PubMed: 1662406]

54. Oosthuizen MJ, Engels F, Van Esch B, Henricks PA, Nijkamp FP. Production of arachidonic and linoleic acid metabolites by guinea pig tracheal epithelial cells. Inflammation. 1990; 14:401-408. [PubMed: 2116377]

55. Kaduce TL, Figard PH, Leifur R, Spector AA. Formation of 9-hydroxyoctadecadienoic acid from linoleic acid in endothelial cells. J Biol Chem. 1989; 264:6823-6830. [PubMed: 2496121]

56. Serhan CN, Chiang N. Endogenous pro-resolving and anti-inflammatory lipid mediators: A new pharmacologic genus. Br J Pharmacol. 2008; 153 Suppl 1:S200-S215. [PubMed: 17965751]

57. Xu ZZ, Zhang L, Liu T, Park JY, Berta T, Yang R, Serhan CN, Ji RR. Resolvins rve1 and rvd1 attenuate inflammatory pain via central and peripheral actions. Nat Med. 16:592-597. 591p following 597. [PubMed: 20383154]

58. Galarraga B, Ho M, Youssef HM, Hill A, McMahon H, Hall C, Ogston S, Nuki G, Belch JJ. Cod liver oil (n-3 fatty acids) as an non-steroidal anti-inflammatory drug sparing agent in rheumatoid arthritis. Rheumatology (Oxford). 2008; 47:665-669. [PubMed: 18362100]

59. Fritsch DA, Allen TA, Dodd CE, Jewell DE, Sixby KA, Leventhal PS, Brejda J, Hahn KA. A multicenter study of the effect of dietary supplementation with fish oil omega-3 fatty acids on carprofen dosage in dogs with osteoarthritis. J Am Vet Med Assoc. 236:535-539. [PubMed: 20187817] 


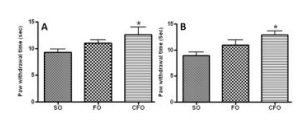

Figure 1.

Plantar assay of (A) C57Bl/6J mice and (B) BW mice after 6 months on diets. Data represent mean \pm SEM $(n=6)$. CFO significantly delayed the pain sensitivity in both the strains of mice compared to SO fed mice at a level of significance $\mathrm{p}<0.05$ by Student's ttest. 


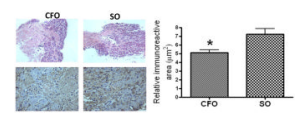

Figure 2.

c-fos immuno-staining of the DRGs isolated from mice fed CFO and SO. L3-L5 Dorsal root ganglion was isolated from mice fed $\mathrm{CFO}$ and $\mathrm{SO}$ and processed for, A) H\&E staining for structural verification (original magnification, 20x). B) Section of a DRG was immunostained with rabbit anti-human c-fos antibody (original magnification, 40×). Development was carried out using the appropriate Vector Stain kit (Vector Labs, Burlingame, CA), and counterstained with hematoxylin. Photomicrographs were recorded using a light microscope. Brown staining represents the presence and intensity of c-fos. C) Quantitation of relative cfos immuno-reactive area in DRG of mice fed diets (mean \pm SE, $n=6$ ). Relative c-fos immuno-reactive area was found to be significantly lower $(\mathrm{p}<0.05$ by Student's t-test) in DRG of CFO fed mice indicating reduced expression of $c-f o s$. 


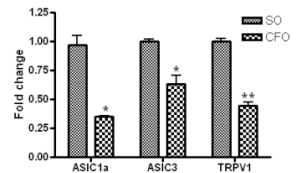

\section{Figure 3.}

Quantitative RT-PCR analysis of ASIC1a, ASIC3 and TRPV1 in dorsal root ganglion of C57B1/6J mice ( $\mathrm{n}=6$ ) fed CFO and SO enriched diets. DRGs were isolated from L3-L5 region of mice fed experimental diets and processed for RNA isolation. Relative quantification of mRNA was expressed as fold change with respect to SO diet using $2^{-\Delta \Delta C t}$ after normalization of the $\mathrm{C}_{t}$ data to that of the housekeeping gene, GAPDH. Data represent the mean \pm S.E.M. A significant reduction in the expression of ASIC1a, ASIC3 and TRPV1 was observed in DRGs of mice fed CFO compared to that in SO fed mice. *p $<0.05$; **p $<0.001$ vs SO fed mice, according to Unpaired Student's t-test. 
Table 1

Composition of AIN-93G diet containing oils.

\begin{tabular}{|l|l|l|}
\hline Ingredients (g) & $\mathbf{4 \%}$ FO & $\mathbf{5 \%}$ SO \\
\hline Casein & 140.0 & 140.0 \\
\hline L-lysine & 1.8 & 1.8 \\
\hline Corn starch & 424.3 & 424.3 \\
\hline Dextrinized corn starch & 195 & 195 \\
\hline Sucrose & 90 & 90 \\
\hline FO & 40.0 & 00.0 \\
\hline Safflower oil & 10.0 & 50.0 \\
\hline Cellulose & 50.0 & 50.0 \\
\hline AIN-93 mineral mix & 35.0 & 35.0 \\
\hline Choline bitartarate & 2.5 & 2.5 \\
\hline AIN-93 vitamin mix & 10.0 & 10.0 \\
\hline TBHQ & 1.0 & 1.0 \\
\hline Vitamin E & 0.4 & 0.4 \\
\hline
\end{tabular}

